\title{
The Role of Eco-Technologic Solutions in Designing Buildings based on Energy-Saving Approach
}

\author{
Anosh Sheikh Kazemha ${ }^{1}$ \\ ${ }^{1}$ Director and Founder of Khane Tarrahan Technical and Vocational Training Complex, Iran \\ Correspondence: Anosh Sheikh Kazemha, Director and Founder of Khane Tarrahan Technical and Vocational \\ Training Complex, Iran. E-mail: alireza_karbalaei_2007@yahoo.com
}

Received: August 23, 2016

Accepted: September 6, 2016

Online Published: January 26, 2016

doi:10.5539/mas.v11n3p112

URL: http://dx.doi.org/10.5539/mas.v11n3p112

\begin{abstract}
Today, along with the increase in population growth and rapid expansion of cities, the need for urban constructions for to social activities is inevitable. In this regard, though considering quantity and variety of construction to accelerate their exploitation is necessary, but saving energy in designing buildings should also be considered both in improving the quality of constructions, and increasing the life of buildings should be considered in designing and building, because the case in buildings increased costs. Eco-technologic is a concept in which designing a building is done by using the best modern technology of the world and following the principle of sustainable development covering the present and future needs in line with optimizing energy consumption and reducing environmental pollution. In other words Ecology seeks to avoid waste of energy. In this study it was tried to investigate the role of Eco-technologic solutions in designing buildings with the approach of energy-saving by the use of library resources with applied-qualitative research method.
\end{abstract}

Keywords: Eco-technologic, designing buildings, saving, energy

\section{Introduction}

The growth of final energy consumption on one hand and the importance of conservation and optimal utilization of fossil fuels on the other hand, lead policy makers' attention to the issues of energy and new ways to manage energy consumption and energy-saving. Today, due to limited energy resources, the environmental pollution, and the security of providing energy, the efficient use of energy is one of the fundamental issues which both energy consumer countries and energy supplying countries are involved with it (Kocharyan et al., 2004). Today's human beings have been in due to disrupting the balance of life, getting away from nature and human values, lack of attention to environmental and indigenous factors, aggressive behavior and instrumental use of nature and see themselves encountering an uncertain and risky future. This issue has led to the gradual formation an approach called sustainable development. Sustainable process is a multi-dimensional flow that with improving the economic situation and the general welfare, along with social justice, is away from environmental and ecologic destructive effects as well as social abnormalities and while supports the needs of the present generation, it keeps the capacity and facilities to fulfill the needs of the future generation. In recent decades, various views and sometimes close to each other were formed under the approach of sustainable architecture through the effect of sustainable development that with the environmental, economic and social goals tries to offer solutions which provide superior quality for present generation and proper heritage for the future (Ghorbani \& Eskandari, 2009).

This study investigates one of the perspectives named eco-technologic considering the use of high technology given the environmental considerations. This approach is new and involves a wide spectrum of buildings and related attempts and utilizes the principles including energy productivity, optimal use of materials and resources, effectiveness, smart design, high technology at the service of sustainability, reducing the costs, increasing the life of the buildings, coolness, warmness, static light, flexibility, reducing the environmental pollutions, proper relationship with cities etc. Eco-technologic has special emphasis on the energy themes, materials and resources, productivity, environmental superior technology, reducing costs, increasing the life of the building, smart design (Ghorbani \& Eskandari, 2009). Eco-technologic architecture, regards architecture as a living organ to provide the environment for human life as another living organism and in this way respect the identity of the built environmental space and although it apparently has the most advanced design techniques, it is closely related to the principles of traditional architecture. In this respect, to make a live organic architecture and the beginning to 
respond the needs and the atmosphere of the today's society a review and deep understanding of traditional architecture can be started then after understanding it, contemporary expression of language can be interpreted (Nikfetrat \& Davoodi, 2013). In the era of modern architecture, energy consumption was diagnosed as a negligible issue and reuse of energy was not a major issue. But today, architects have the responsibility and design opportunity to reduce energy and their responsibilities get much more; because, construction affects the lives. Therefore, the architecture which maintains energy can be more pleasant, sustainable and elegance. This architecture can be less expensive than conventional architecture. Operating costs comes down and due to reducing the need for heating and cooling facilities the initial cost is decrease (Kocharyan et al., 2004). For this reason, this study with the aim to find solutions to reduce energy consumption in buildings with applied and qualitative method investigates the role of Eco-technologic solutions in designing buildings with the approach of energy-saving.

\section{Energy Consumption in Buildings}

During recent decades one of the most important global challenges was energy crisis that over the past two centuries, the industry can be considered as the most important achievement of the modern age that due to lack of awareness and understanding of different dimensions of the industry by consumption-oriented society has caused negative consequences such as global warming and depleting energy resources and increasing pollution through excessive use of fossil fuels and caused irreparable impacts to the environment; therefore, authorities seek ways to save energy and the appropriate use of energy and introducing the need to use renewable and sustainable energy (solar, water, wind, etc.) as a suitable alternative. Since the buildings' form has a significant impact on their energy consumption, environmental potentials should be used in order to save energy and enhance the quality and comfort of residential environment and make the environment healthy through correct forms in designing buildings. Therefore, all designing projects should use the environment as a play to reduce or eliminate the need to fossil energy (Jafarzadeh \& Khoshnevis, 2015).

One of the most important ways to reduce energy consumption in recent years and has been of interest to many countries is to develop standards for energy consumption in buildings according to architectural plans and specifications of the materials used in construction. Building energy consumption is very high in the world. The buildings sector consumes 48 percent of the energy, $40 \%$ for buildings and $8 \%$ for the construction phase. This energy is produced from fossil fuels and the carbon dioxide and is the main cause of global warming. The unclean energy should be replaced by clean, renewable energy like wind, solar and biomass (Qobadian \& Feiz-Mahdavi, 2010).

Table 1. Energy consumption of buildings (Nasrollahi, 2011)

\begin{tabular}{cl}
\hline $\begin{array}{c}\text { Reducing the buildings } \\
\text { energy consumption }\end{array}$ & $\begin{array}{l}\text { The available buildings } \\
\text { The new buildings }\end{array}$ \\
\hline New buildings concentration & $\begin{array}{l}\text { The high demand for housing } \\
\text { Higher saving potential of new buildings } \\
\text { Relatively low useful life of existing buildings }\end{array}$ \\
\hline Energy consumption of buildings \\
\hline 1 & $\begin{array}{l}\text { Housing construction sector with more than } 40 \% \text { of energy consumption is } \\
\text { the biggest energy consumer in Iran. }\end{array}$ \\
\hline 2 & $\begin{array}{l}\text { The average of energy consumption of buildings in Iran is } 2.5 \text { times more } \\
\text { than the average of the world consumption. }\end{array}$ \\
\hline 3 & $\begin{array}{l}\text { More than 98\% of the energy consumption of buildings in Iran is provided } \\
\text { by oil and gas products. }\end{array}$ \\
\hline 4 & $\begin{array}{l}\text { Construction and Housing sector is one of the main sources of producing } \\
\text { pollution. }\end{array}$ \\
\hline 5 & $\begin{array}{l}\text { Construction and Housing sector in Iran are accounted for about 26.4 } \\
\text { percent of the carbon dioxide emissions. }\end{array}$ \\
\hline Compelling reasons to reduce energy consumption. \\
\hline 1 & $\begin{array}{l}\text { Reducing energy consumption in Construction and Housing sector will have } \\
\text { a significant impact on the country's total energy consumption. }\end{array}$ \\
\hline 2 & $\begin{array}{l}\text { The removal of energy subsidies and increasing energy prices increased the } \\
\text { importance of energy-saving in buildings. }\end{array}$ \\
\hline Reducing building energy consumption from economic and environmental \\
\hline
\end{tabular}




\begin{tabular}{ll}
\hline & point of view is essential. \\
\hline 4 & $\begin{array}{l}\text { The potential for energy savings in Construction and Housing sector is more } \\
\text { than other sectors. }\end{array}$ \\
\hline 5 & $\begin{array}{l}\text { Reducing energy consumption in this section is easier and with less } \\
\text { investment than the other parts available. }\end{array}$ \\
\hline
\end{tabular}

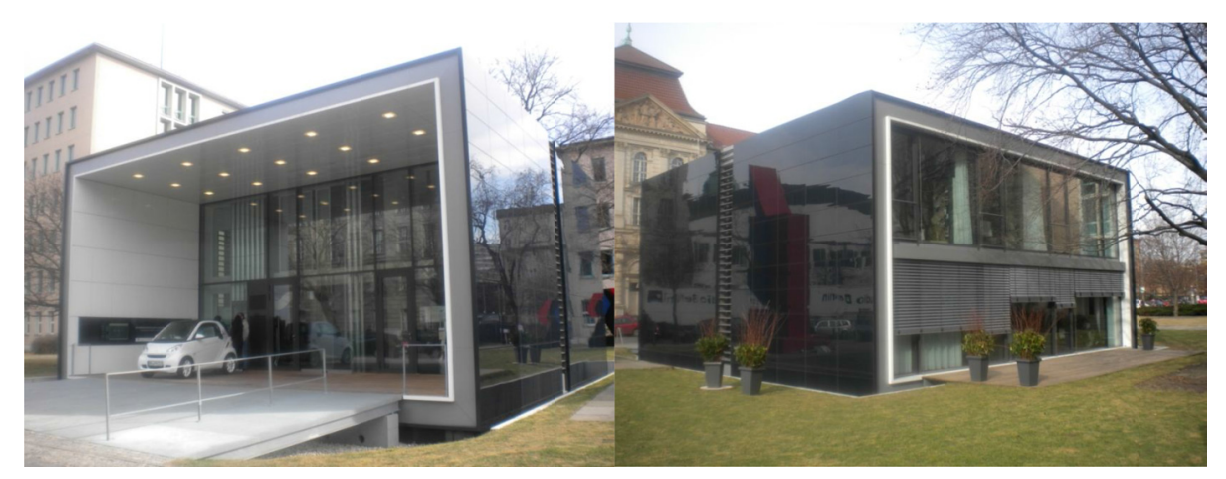

Figure 1. Model of building with low energy consumption (Nasrollahi, 2011)

\section{Ecology}

Ecology is a holistic science that studies the relationships and dependencies of mutual reaction between the planet's animate and inanimate systems. Today, ecology studies the relationship between creatures and nature and analyzes it. Ecology is the branch of biology that deals with the life environment in relation to living creatures and ecological design is a concept that means to reduce the damage caused by the design using the benefits of nature in the design. In general, ecology studies the interaction between organisms and their environment. Environment includes physical characteristics composed of biotic and abiotic factors. Therefore, ecology is a broad discipline that includes many small systems, Such as Eco-physiology that examines how creatures' physiological functions effects on their interactions with the environment. Environment ecology studies, energy and material flows between biotic and abiotic elements of the ecosystem (Rezaei, Shadpour, 2014).

Table 2: Eco-technologic design (Farkhan, Moradi \& Sharifi, 2014)

\begin{tabular}{|c|c|}
\hline \multirow{2}{*}{ Ecology } & $\begin{array}{l}\text { Knowledge of the relationship and interaction between living organisms and } \\
\text { non-living( climate, soil and living environment) }\end{array}$ \\
\hline & $\begin{array}{l}\text { The Knowledge of the harmful effects of modern civilization on the environment with } \\
\text { a view of preserving natural resources }\end{array}$ \\
\hline \multirow[t]{3}{*}{ Economy } & With strict management and saving resources such as materials, labor and ... \\
\hline & A functional and appropriate training with organized system \\
\hline & protectoral, efficient and thrifty Consumption \\
\hline \multirow{4}{*}{$\begin{array}{l}\text { Eco-technologic } \\
\text { goals }\end{array}$} & Reducing waste and energy distribution in the environment \\
\hline & The use of recyclable materials nature \\
\hline & Reducing the production of passing influences on human health \\
\hline & Antitoxin and materials \\
\hline \multirow{5}{*}{$\begin{array}{l}\text { Eco-technologic } \\
\text { Design Principles }\end{array}$} & Reducing the island heat effect \\
\hline & Conservation of energy \\
\hline & Reducing pollution \\
\hline & Conservation of water \\
\hline & Protection of animals \\
\hline
\end{tabular}

\subsection{Eco-Technologic Architecture}


In the new styles called echo -Tech (Ecology + Technology), Technology is not against nature but along and in parallel with nature to exploit more of the environmental resources and human welfare. In the recent work of the architects of this style, there is always a cross section of the building along with beautiful pictures of their buildings, in which the way to use climatic factors with the help of equipment such as smokestacks, reflective mirrors, smart shells, greenhouses, glass stairs and heat exchangers are shown. The form of the building in the cross section was also designed considering the angle of solar radiation and wind speed and direction in different seasons (Qobadian, 2003). Designing in the style is based on the issue that building is a small part of the surrounding environment and should act as part of the ecosystem and placed in the life cycle. Eco-technologic architecture is a popular design and the quality of interior spaces is of particular importance (Aryanpour, Kameli, 2013).

Undoubtedly, high quality regardless of the nature of space and ventilation systems and the proper exposure is not provided. In addition, what is considered as a phenomenon from sustainability and the building survival itself, construction with high quality and using the materials with long-term survival should also be considered. To achieve such conditions the efficient management and use of the latest technologies should be regarded. Achieving high standards of quality, safety and welfare that actually provides human health is an important objective of Eco-technologic (Qobadian, 2003). Eco-technologic architects call the building shell as a second skin. The purpose of the first skin is the skin of the human body. Second skin like the first skin reacts against cold, heat, moisture and air. Some of the buildings' shell also shows appropriate response to the environmental conditions in different seasons. Using double glass, blinds and moving insulation materials, things such as the sun, shade, air drafts and heat loss are controlled by a computer system during the night and the day and during the cold and hot seasons of the year. Rogers named the buildings as a chameleon which adapts itself to different environmental conditions in order to meet the needs of the residents of the building and most efficient use of energy. Rogers writes about the future buildings as follow:

Future buildings are linked dynamically with the surrounding climate; in architecture, microelectronics hidden from the eyes and biotechnology will replace mechanical systems; buildings, the city and its people as an integral organic system are placed in moving and changing context designed precisely and perfectly. Instead of beams, columns and panels and other structural elements, a continuous and interconnected shell will be replaced. The moving robot, using electronic and biotechnological systems, will have many of the characteristics of living organisms. (Ghorbani, Eskandari, 2009).

\subsection{Reducing the Buildings Energy Consumption with Eco-Technologic Architectural Design}

Reducing the building energy consumption is not done only through the use of appropriate materials and building installations, But with an architectural and urban design appropriate with the climate, buildings energy consumption can be reduced. Architectural and urban design has high effect on the energy consumption of buildings. The potential of the savings is very high in some areas of climate in Iran and this method of energy-efficiency is cost-free. Due to economic, social and cultural conditions, inexpensive ways to reduce the energy consumption in buildings is of particular importance. One of the low or even no cost ways to reduce energy consumption in buildings is urban planning and architecture approach reducing energy consumption, and are better than other methods both economically and environmentally. Energy efficiency and urban planning and architecture are easily accessible to its practical functionality is very high.

Developing regulations of architecture and urban planning to reduce energy consumption in buildings and neighborhoods' units could be a major reduction in energy consumption of residential complexes and buildings without increasing the cost and construction of the buildings (Nasrollahi, 2011). In the description of the importance of saving energy in architecture, this may be enough that energy conscious design of buildings does not need expensive, dirty and irreversible energy. Due to the fact that global warming is completely resulted in an increase in energy consumption, the first important issue of architectural design is that in order to protect the quality of life on earth, eco-technologic design should be used. One reason is that it leads us to take advantage of solar cells, active heating (hot water) passive heating (space heating) lighting and shadows. Therefore, shading is contrary to collect solar energy. This is one of the most important strategies of the solar energy design because it can reduce air conditioning costs so much (Jafarzadeh, Khoshnevis, 2015).

Table 3. Reducing buildings energy consumption through eco-technologic architectural design (Nasrollahi, 
2011).

\begin{tabular}{lll}
\hline \multicolumn{2}{c}{ Major architectural factors affecting building energy consumption } \\
\hline 1 & Thermal shell of the building \\
\hline 2 & Heating, cooling and ventilation system of buildings \\
\hline 3 & Buildings form and architecture and of &
\end{tabular}

\begin{tabular}{lc}
\hline & Strategies of energy efficiency in the building sector \\
\hline 1 & Reducing the energy consumption of buildings with architectural design \\
\hline 2 & Developing standards and energy labels for buildings \\
\hline 3 & Encouraging Supports to for buildings with energy efficient \\
\hline 4 & Making culture to reduce energy consumption in buildings \\
\hline 5 & Construction of model buildings \\
\hline
\end{tabular}

\subsection{Eco-Technologic Solutions in Designing Buildings}

In half of the twentieth century energy has been the most important subject. Today's human has been on the verge of a modern era of evolution which is probably more important than Industrial Revolution. During the coming decades in addition to environmental issues and global warming, different kinds of energy costs for different uses undoubtedly had a significant growth and among them, limited fossil fuels as an energy source has always maintained a rising share of their consumption and still continues (Shams et al., 2015). Using the environment as a system, development of eco-technologic goals beyond the issue of energy conservation, the mutual effect among people, space and technology in a sustainable pattern all significantly affect the culture of architecture. They make designers familiar with the concept of reuse, recycling, considering sources and the use of materials, water conservation and health of construction workers and residents of the building. This new mindset requires a new technology and should be borrowed from other industries. The proposed technologies, reviving old technologies or other technologies that are still capable of growth, all cause the creation of a new perspective. This is the type of recognition that seeks to create healthy buildings. The human environments created by architects affect healthy both physically and psychologically.

Buildings can cause stress or suppress it. Buildings can cause cancer or contribute to longevity. In terms of utility, technology and sustainability, especially in the workplace, are known as an important package of measures. Praising eco-technologic buildings is not only due to their energy conservation, but for their health growth and social cohesion as well. Technologies used by designers are kind of cultural statement. The construction of buildings is not a free value but influenced by many factors such as cost, manufacturability, sustainability and aesthetics (Aryanpour, Kameli, 2013).

In eco-technologic design, it is needed that the architect to look at nature as a dynamic system and knows the artificial environment to it. This relationship is called continuity. The basis of eco-technologic design is to understand the relationship between living and non-living components of nature. In more precisely words, eco-technologic design is a useful and productive partnership of nature. Additionally, eco-technologic design should work in order to repair, rebuild and renew the natural systems. It creates an internal communication and coordination that is completely in contrast with artificial boundaries; therefore, eco-technologic design should be regarded as a communication in all aspects including quick energy management and consumables in artificial system in accordance with the ecosystem of the living world. The importance of a building design based on eco-technologic features is an obvious and clear issue because such activities not only affects the environment but also but also its effects will affect the next generations and leads to the survival and sustainability of the environment for them (Nikfetrat and Davoodi Azad, 2013). Eco-technologic building is a movement in contemporary architecture whose goal is to create buildings with energy efficiency and the development, environment and management affecting on natural resources and the active and passive energy, control solar 
energy and materials with the least possible damage to free resources, water, land and air (Rezaei, Shadpour, 2014).

Table 4. Building design criteria with the approach of eco-technologic (Safari and Malek Mahmoudi, 2011; Shahosseini and Gholhaki, 2008; Azariyun, Hassanzadeh and Pesteh, 2005)

\begin{tabular}{|c|c|}
\hline Healthy materials & $\begin{array}{l}\text { In general, natural building materials are healthier than other building materials. The } \\
\text { problem is that the lack of technical efficiency of organic materials often affects the } \\
\text { products produced by architects. Although traditional materials, partly due to poor } \\
\text { performance and shape have been neglected, but are often re-considered as a result of their } \\
\text { definitive health. Of course they have been popular again and new technologies were } \\
\text { developed to use them in new ways. }\end{array}$ \\
\hline $\begin{array}{l}\text { Conformity with } \\
\text { climate }\end{array}$ & $\begin{array}{l}\text { One of the criteria for construction with eco-technologic approach is to consider the } \\
\text { climatic design of each region. It is clear that the materials used in a humid climate, cannot } \\
\text { be used in the hot and dry climate and more importantly, the materials are the result of the } \\
\text { evolution of human knowledge about the compatibility of life in nature. }\end{array}$ \\
\hline Proper positioning & $\begin{array}{l}\text { Finding a suitable place for the construction is another construction criterion in } \\
\text { eco-technologic style. In order to construct a sustainable building proximity and privacy } \\
\text { should be checked. Also the use of inefficient equipment in a building to produce clean } \\
\text { energy causes high initial cost and efficiency loses. }\end{array}$ \\
\hline $\begin{array}{l}\text { Proper design of } \\
\text { the building }\end{array}$ & $\begin{array}{l}\text { The architect is responsible to design buildings and in order to show the approach of } \\
\text { eco-technologic everywhere in the building, a proper map is needed which in addition to } \\
\text { following the aesthetic points, has the maximum utilization of available energy on the site. } \\
\text { Moreover, the facilities should be used in designing which have the least energy loses and } \\
\text { leaks. }\end{array}$ \\
\hline $\begin{array}{l}\text { Design } \\
\text { compatible with } \\
\text { nature }\end{array}$ & $\begin{array}{l}\text { Another design compatible with the nature criteria is façade design inspired by nature. A } \\
\text { construction makes human think of the elements of the nature can be regarded a kind of } \\
\text { making culture. }\end{array}$ \\
\hline $\begin{array}{l}\text { Recognition of the } \\
\text { society }\end{array}$ & $\begin{array}{l}\text { Recognizing the society is one of the responsibilities of an architect. According to the use } \\
\text { needed for projects, the elements and components of design are formed. For example, if the } \\
\text { purpose is to design a school with the approach of eco-technologic, the school should be } \\
\text { designed so that in addition to saving energy and minimizing environmental pollutions, it } \\
\text { should have educational approach. Unconventional sun shading should also be prevented } \\
\text { because in summer and winter, engage people with problems such as lack of balance in } \\
\text { temperature and makes it unusable. }\end{array}$ \\
\hline $\begin{array}{l}\text { Considering the } \\
\text { culture }\end{array}$ & $\begin{array}{l}\text { Another criterion for a suitable design is to consider the users' culture. The building design } \\
\text { should be in such a way that contrary to the beliefs, religion and ethnicity does not appear. }\end{array}$ \\
\hline $\begin{array}{l}\text { The use of } \\
\text { materials } \\
\text { compatible with } \\
\text { nature }\end{array}$ & $\begin{array}{l}\text { Recyclable materials and their re-use will help to conserve natural resources. Also materials } \\
\text { such as wood which is biodegradable reduce construction waste. }\end{array}$ \\
\hline $\begin{array}{l}\text { The use of } \\
\text { renewable energy } \\
\text { sources }\end{array}$ & $\begin{array}{l}\text { Since Iran is a sunny country, maximum use of this source can be achieved using solar } \\
\text { cells. Also, wind energy in areas that are windy, can be used. Also, by creating heating and } \\
\text { cooling systems from the floor using energy from solar panels pleasant temperature can be } \\
\text { provided to the environment. }\end{array}$ \\
\hline $\begin{array}{l}\text { Maintaining } \\
\text { mutual interaction } \\
\text { with nature }\end{array}$ & $\begin{array}{l}\text { One of the most important reasons to be infected to psychological and mental diseases is to } \\
\text { be away from nature due to industrialization. In buildings with eco-technologic approach, } \\
\text { this mutual relationship should be effectively felt. Using natural ventilation is one of the } \\
\text { ways. Considering the prevailing wind direction, suitable natural ventilation can be } \\
\text { provided for the residents of the building. Also considering yard performance in buildings, } \\
\text { can help it. Using appropriate green space in terms of thickness and type, many adjacent } \\
\text { problems, air pollution and noise pollution can be reduced. Green roof and green wall is a } \\
\text { perfect example of this point. }\end{array}$ \\
\hline $\begin{array}{l}\text { Principled } \\
\text { construction }\end{array}$ & $\begin{array}{l}\text { Unfortunately, due to unprincipled constructions in different areas, every year damages to } \\
\text { the buildings of the monuments due to natural and man-made causes are seen. Among } \\
\text { natural causes, natural disasters such as earthquakes can be mentioned. Among man-made }\end{array}$ \\
\hline
\end{tabular}


causes, unprincipled digging is the factors damage the buildings. One of the criterions for construction with the approach of eco-technologic is a construction that in emergency situation has the least damage to human and environment. Therefore, the use of preventive structures and light materials yet powerful in the construction is essential.

Adjusting the temperature of interior spaces
Preventing the increase or decrease due to the temperature of spaces
Adjusting, turning on and off the heating and cooling systems on time
The use of the heating and cooling systems only in the required time and spaces
The correct adjustment of the screen and moving shadows in suitable time
The correct adjustment of the screen and moving shadows in suitable time

Figure 2. The behaviors affecting energy consumption of buildings (Nasrollahi, 2011)

\section{Buildings Built in Eco-Technologic Style}

By looking at what has been done in the field of architecture it can be realized that the design custom of the building has changed over time, from blocking external environment for the protection of internal spaces to put nature and natural energy in design. For example, Japanese's re-use of deep cymatium and Shoji valves made of special glass can be noted that both are the Japanese traditional architecture compatible with the nature. Ventilation, lighting and other mechanical systems, are broad technologies that both residents and architects benefit them. Natural ventilation by allowing airflow from the ceiling, suitable ventilation through night refinery and blowing air under the floor, light control and so on are achievements and innovative forms that while following them in some buildings, have been able to use energy and natural resources such as heat and sunlight, wind, geothermal energy and rainwater. In the meantime various mechanical methods for saving energy and new production systems, with the least adverse effect to the environment, have been used. Green buildings design is also a substitute for administrative buildings with air conditioning and power consumption and a serious attempt to tackle the problem of air pollution and high energy consumption in these buildings. The shape of the building is achieved through wind tunnel tests and using demonstrative models of the around buildings (Aryanpour, completeness, 2013).
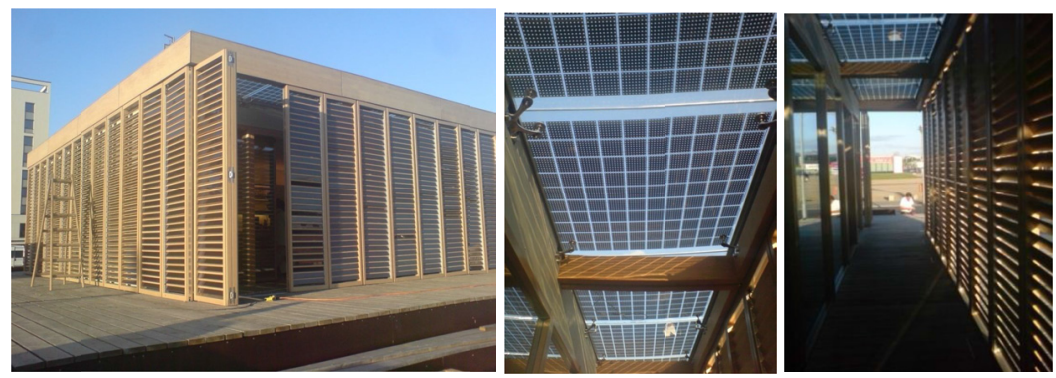

Figure 3. Buildings built in eco-technologic style (Nasrolahi, 2011)

\section{Conclusion}

Along with increasing population growth and development of cities, and construction activities, the use of new construction systems and sustainable materials are necessary. The technologic features of the architecture, especially in eco-technologic architecture makes the alignment of structures and architectural technology more visible so that the use of materials and construction products is also very important. What is internationally being formed as eco-technologic architecture now is in fact, orientation and efforts to help high tech and innovative to the aims and principles of sustainable development in architecture and construction. In other words eco-technologic architecture tries to gather ecological, artistic and technical resolutions together; however, eco-technologic architecture needs to be implemented during the pre, while and post phases of constructing of the building. Among the most important solutions of the approach to save energy in designing buildings can name energy productivity, optimal use of materials and resources, effectiveness, smart design, high technology at the service of sustainability, reducing the costs, increasing the life of the buildings, coolness, warmness, static 
light, flexibility, reducing the environmental pollutions, proper relationship with cities etc. in line with eco-technologic solutions to save energy in buildings it is possible to apply techniques such as considering the orientation and structure of the building based on the climate and external environment, creation of small ideal climate, static coolness, warmness and lightening, smart control of elements and components in different hours of a day and seasons of the year, combination of green space and life space, keeping and developing perspectives, analyzing the building's behaviors, smart utilization of thermal mass, smart shells, ventilation chimneys, creating a greenhouse, double-glass windows, shutters and thermal isolation, the development of combined efficiency, maximum use of space etc.

\section{References}

Aryanpour, M. B., \& Kameli, M. (2013). Ecotech architecture, a symbol of sustainable architecture, the first national conference on sustainable architecture and urban spaces, Mashhad.

Azariyun, Y., Hassanzadeh, S., \& Pesteh, M. (2005). Optimizing Energy consumption in buildings using solar water heaters and floor heating systems, Fourth Conference on optimizing fuel consumption in the building, Tehran: the organization of optimizing fuel consumption.

Farkhan, M., Moradi, S., \& Sharifi, M. (2014). The relationship between the environment and its impact on sustainable architecture, the first national conference on architecture, civil engineering and urban environment, Hamedan, Permanent Secretariat of the Conference.

Ghorbani, P., \& Eskandari, H. (2009). Eco tech architecture, environmental approach in architecture, the third conference on Specialized Exhibition of Environmental Engineering, Environmental Engineering Association of Iran, Tehran.

Jafarzadeh, Z., \& Khoshnevis, A. M. (2015). Explaining the principles of sustainable architecture based on local climatic design, National Conference on architecture and native urbanism Yazd, Iran.

Kocharyan, A., Bidi, M., Mansouri, F., \& Alipoor, M. (2004). Comprehensive software of optimizing energy consumption in residential buildings, the $19^{\text {th }}$ International Conference on Electrical, Energy Research Institute Energy and Environment, Department of Energy and consumption management.

Nasrollahi, F. (2011). The principles of Architecture and Urbanization, reducing energy consumption of buildings, Iran National Energy Committee meeting

Nikfetrat, M., \& Davoodiazad, H. (2013). The role of architecture in the design of high-rise buildings, instances and examples of Ecology, National Conference on sustainable architecture and urban development, Bukan: Sazeh Kavir Company.

Qobadian, V. (2003). Principles and concepts in contemporary architecture of the West, the Cultural Research Bureau.

Qobadian, V., \& Feyzmahdavi, M. (2010). Theoretical principles and the use of energy in buildings, Tehran: SAMT Publication.

Rezaei, D., \& Shadpour, M. (2014). Evaluation of ecological solutions in the design of living space with the approach of sustainable systems, National Conference on Urban Planning, Urban Management and Sustainable Development, Tehran.

Safari, Z., \& Malek Mahmoudi, R. (2011). Green school, a sustainable approach to design training centers, $2^{\text {nd }}$ conference on sustainable architecture, Hamedan: Sama educational and cultural center.

Shahosseini, F., \& Gholhaki M. (2008). Green Building, $14^{\text {th }}$ Conference on Students' Civil Engineering, Semnan: Semnan University.

Shams, M., Sadeghi, S., \& Esmaeili, A. (2015). Façade with two skins, architectural solution in cold mountain climate, the international conference on architecture, urban planning, civil engineering, art and the environment; horizons of the future, look to the past, Tabriz.

\section{Copyrights}

Copyright for this article is retained by the author(s), with first publication rights granted to the journal.

This is an open-access article distributed under the terms and conditions of the Creative Commons Attribution license (http://creativecommons.org/licenses/by/4.0/). 